\title{
Understanding UK Ethnic Minority Entrepreneurship from an Enterprise Culture Perspective
}

\section{Wing Lam/Phil Harris/Sen Yang}

Objectives: This paper is aimed at examining the enterprise culture within different ethnic groups (ie. the enterprise subcultures) in the UK. The research aims to investigate the interplay between individuals and their institutional context (esp. social and cultural context), how the different institutional context then shapes the different enterprise cultures, leading to differentiated ethnic business characteristics and consequently different levels of entrepreneurial activity in different ethnic communities.

Prior work: Unequivocal evidence shows that certain ethnic groups display higher levels of entrepreneurial activity than their white counterparts. Despite the large amount of work that has been dedicated to ethnic minority entrepreneurship (eg. Aldrich et al. 1985, Ram, 1997, Ibrahim and Galt, 2003), there is a lack of coherent conceptual and analytical framework that addresses the links between different factors contributing to ethnic minority entrepreneurship. This paper takes forward the available empirical evidence and theoretical constructs into a conceptual and methodological framework to aid understanding of ethnic minority entrepreneurship.

Approach: A process-oriented research framework to investigate the enterprise culture within different ethnic groups (i.e. the enterprise subcultures) is proposed rather than one oriented primarily towards the differentiation of characteristics.

Results: A large-scale national survey in the UK is adopted. The findings of the quantitative fieldwork will form the central part of this paper.

Implications: Understanding how and why certain ethnic groups are more entrepreneurial may assist the different parties in different ways. Firstly, learning from the more entrepreneurial subcultures may contribute to the development and implementation of more effective public policies and efficient service delivery programmes. Secondly, advancing understanding of ethnic communities helps to support more informed decisions by policy makers and local support agencies through improved anticipation and greater understanding of responses. Thirdly, it helps entrepreneurs and potential entrepreneurs to have a better understanding of the nature of their perceived barriers and constraints by demonstrating potential solutions successfully employed by other subcultures.

Value: The conceptual and methodological development of this study has the potential to build the link between relevant parties and pave the way forward for ethnic entrepreneurship research.

Keywords: Ethnic Minority, Enterprise Culture, Social Construction, Social Network 


\section{Enterprise Culture, Subcultures and Ethnic Minority Entrepreneurship}

\section{Introduction}

In the UK, according to Global Entrepreneurship Monitor's latest UK report (GEM, 2017), nonwhite ethnic minorities as a group continue to be more entrepreneurial, with a TEA rate of $14.5 \%$ than their white counterparts $(7.9 \%)$. Based on the observation that some ethnic groups have higher rates of business formation and ownership than others, raises questions about how and why, under the same political and economic environments, some groups have entered business ownership in numbers disproportionate to their group's size (Clark \& Drinkwater, 2000; Collins \& Fakoussa, 2015; Monder Ram \& Smallbone, 2003).

There are many and varied explanations for the reasons and factors that give rise to ethnic minority entrepreneurship, attracting the interest of policy makers and scholars from different disciplines (Howard Aldrich et al., 1985; Bagwell, 2015; Fairlie \& Meyer, 1996; Jones et al., 2010). Traditional debates on ethnic minority business have been the push and pull factors, which continue to dominate the extant literature. The arguments that have been proposed by scholars emphasise the interplay between the pull and push factors (Jones \& Ram, 2003; Leung, 2001; Moder Ram et al., 2000). However, a comprehensive framework to address these complex issues does not exist. This paper is aimed at addressing this gap by taking forward the contribution of the extant literature of ethnic minority entrepreneurship and contributing to the theoretical and conceptual development in this area. In the following section, research regarding ethnic minority entrepreneurship is considered in more detail before discussing the theoretical framework used to inform this study.

\section{Ethnic Minority Entrepreneurship}

Traditional debates on ethnic minority business have been the push and pull factors, which continue to dominate the extant literature. Studies argue that ethnic minorities are pushed to start up their own business (Haugen \& Carling, 2005; Khosravi, 1999; Min, 1988). A major push factor for ethnic business entrepreneurship is the unfavourable opportunity in the job market. As Min (1988) observed, immigrant group members have not been able to turn their previous education and experience into positions comparable to those they held prior to migrating, because they had language problems or lacked proper credentials. These persons, finding their way into well-paying white collar work blocked, have sometimes turned to entrepreneurship. Min's arguments for ethnic minority entrepreneurship is challenged by other studies which argue that the second or third generation of ethnic immigrants, who are brought up and educated in the host country, have similar levels of entrepreneurial activity as their immigrant parents or grandparents (Haley et al., 1998; Redding, 1990).

The 'pull' factor studies, on the other hand, focus mainly on opportunity or resources of the Ethnic Minority Business (EMB) and suggest that certain ethnic groups possess certain unique opportunity or resource that give rise to the entrepreneurial activities. Early studies on opportunity argue that the initial market for ethnic entrepreneurs typically arises within the ethnic community itself (Braadbaart, 1995; Jones et al., 2012; Light, 1972; Wong, 1995). If ethnic communities have special sets of needs and preferences that are best served by those who share those needs and know them intimately, then ethnic entrepreneurs have an advantage. Servicing these special ethnic consumer needs involves a direct connection with the immigrants' homeland and knowledge of tastes and buying preferences - qualities unlikely to be shared by larger, native-owned competitors (Howard Aldrich et al., 1985; Carino, 1995; Suryadinata, 1995; Wong, 1995). As immigrants are likely to have special problems caused by the strains of settlement and assimilation and aggravated by their distance from the government mechanism of service delivery, the business of specialising in the problems of immigrant adjustment is another unique opportunity for certain ethnic groups ( $H$ Aldrich \& Waldinger, 1990; Chan \& Chiang, 1994; Hodder, 1994; Weidenbaum \& Hughes, 1996). Other factors which provide a unique opportunity for ethnic minority business include ethnic residential concentration (H Aldrich \& Waldinger, 1990; Ang \& Hong, 2000; Bates, 1997) or niche market needs that are not met by their white counterparts (Silverman, 1999; Waldinger et al., 1990). 
Another group of 'pull' factor studies focus on resources such as financial (Godley, 1996; Smallbone et al., 2003), human and social capital (Bagwell, 2015; Jones et al., 2010; Marger, 2001).

Ethnic minority businesses are believed to possess beliefs, values and traditions that predispose them to succeed in business, regardless of where they find themselves (Chan \& Chiang, 1994; Haley et al., 1998). This is supported by earlier work by Hirschman (1982) who argued that an ethnic group's socioeconomic achievements are partly a function of the human capital of individuals and the socio-cultural orientation - motives, ambitions - derived from group membership. In other words, if one can describe the social group of an individual entrepreneur, one can then infer how and why new businesses are founded (Thornton, 1999).

The 'sociocultural perspective' is criticised for its presumption of the existence of a stereotypical standard that all members of the group display and presume that behaviours are evoked regardless of the group member's situation (Howard Aldrich \& Zimmer, 1986). These studies argue that there are shared values, beliefs and traditions in a social group. These shared meanings are then instilled into the members of the social group automatically, regardless of their individual situation. Granovetter (1985) argues that individuals do not act like atomised actors who follow the social norms and customs mechanically. He emphasised the importance of the individual's embeddedness in their social relations and their social interaction. Therefore if the social situation of individuals are fully analysed, their behaviour looks less like automatic application of "cultural" rules and more like a reasonable response to their present situation (p.506).

In other words, a major limitation of the social/cultural perspective is that they tend to focus on a specific set of values, beliefs, traditions and other cultural factors in the social group. As a result, the situation of the individuals and the social context are ignored. The social and cultural factors are presumed to be static and exist 'out there' and will somehow be instilled into members of the social groups. This is criticised by many studies which emphasise the importance of other factors in the micro and macro environment in the process of entrepreneurship.

In summary, in reviewing the ethnic minority business literature a common weakness can be identified. A common theme of ethnic minority business studies is that the ethnic groups adapt to the resources made available by their environments, which vary substantially across society and over time (H Aldrich \& Waldinger, 1990). Though these studies hint at the interaction between the different ethnic groups and their environment, the notion of interaction between individuals and environment is not operationalised. There is a temptation then for studies to focus on one single variable - one privileged actor to explain ethnic minority entrepreneurship (Orru, 1997). However, whilst one cannot conclude that any of the above factors are unimportant, it is also believed that there is no single factor or perspective that can adequately explain entrepreneurship. From this review, the importance of a research framework which recognises this is highlighted. Redding (1990) criticised the cause-and-effect assumption of major studies and argues that "in no case has a single cause won universal acceptance'. In addition, he argues that the word 'cause' raises more fundamental problems. Redding emphasises the reciprocal, interactive nature of different factors and the importance of multivariant, multi-level analysis. This is consistent with the review of extant ethnic business studies which suggest that no one factor, be it finance, human, resource or social network, can fully explain the ethnic business phenomenon. This highlights the importance of a more comprehensive conceptual framework to advance understanding ethnic business.

To sum up, evidence from the extant literature shows that ethnic groups have different source of capital, including finance, human and social capital, mainly due to their social networks and ethnic communities that they are embedded in. In addition, their different cultural and social values have a major impact in shaping their attitudes, motives and drives towards entrepreneurship. This has not only highlighted the importance of social embeddedness in the ethnic entrepreneurship, but also provided strong evidence that the different ethnic groups are embedded in different 'enterprise cultures' - with different meanings, values, attitudes towards entrepreneurship and different supportive environments which influence the availability of entrepreneurial resources. Despite a significant number of comparative studies on different 
ethnic groups which focus on aspects such as finance (Godley, 1996; Smallbone et al., 2003), resources and opportunity (Teixeira, 2001), attitudes (Wright et al., 2003) and networks (Monder Ram, 1994), there remains a lack of attention on the interrelationship between the different factors and the individuals in the different ethnic groups. It is argue that a processoriented, enterprise culture perspective may have the potential to shed new light to aid the understanding of EMBs.

\section{Conceptualising enterprise cultures and enterprise subcultures}

In the UK, the declared task of the UK government throughout the 1980s was to re-energize Britain by encouraging and 'enterprise culture' (Legge, 1995). As such the term 'enterprise culture' is more an ideology than a strategic framework in the social re-engineering process (Green \& May, 2003). Despite the massive promotion of 'enterprise culture' by different governments, especially the English speaking countries throughout the $80 \mathrm{~s}$ and $90 \mathrm{~s}$, there is a lack of conceptualisation of enterprise culture. Ritchie (1991) pointed out that 'enterprise culture' remains a particularly difficult notion to frame and rigorously evaluate (p.17). As a result, 'the discourse of the enterprise culture has tended to pursue arguments that suit its own purposes, and get conducted on its own terms. This has very often led to the same self-serving conclusions being reached'(p.19). Ritchie (1991) recognise the 'puzzling paradox of an enterprise culture which is simultaneously ill-defined, rarely measured, vaguely signalled, and seldom clearly visible, yet which permeates many different discourses.'(p.20). The frustration of defining enterprise culture is shared by Burrows and Curran (1991) who conclude that 'whenever there are attempts to give the "enterprise culture" any analytic solidity it melts. Even its advocates appear confused over its meaning' (p.9). Despite the confusion and frustration in conceptualising and defining 'enterprise culture', the term 'enterprise culture' continues to be popular among scholars, political parties and policy makers (Chapman, 2003; Cohen \& Musson, 2000; SBS, 2003).

Despite the lack of consensus, it is possible to identify a common feature of enterprise culture studies - a strong enterprise culture is positively related to entrepreneurship and entrepreneurial activities - though there is a lack of agreement on how this is so. To aid understanding of enterprise culture, Gibb (1987) proposed a research framework which listed the components of enterprise cultures as 1 ) abundant positive role images of successful independent business; 2) opportunity to practise entrepreneurial attributes reinforced by society culture during formative years; 3 ) provision formally and /or informally of knowledge and insight into the process of independent business management; 4) network of independent business/family contacts and acquaintances reinforcing familiarity and providing market entry opportunities and 5) ample opportunity for familiarisation with small business tasks especially youth (p.14). According to Gibb (1987), the combination of these circumstances on a sufficient scale can be said to underwrite the existence of an "enterprise culture". Central to Gibb's framework of enterprise culture is the existence of environment that provides individuals the opportunity for exposure to entrepreneurship.

A strong enterprise culture is considered as 'a culture where people with the initiative, skills and drive to start and run a successful business have the confidence to do so and consider it to be a realistic career choice.'(SBS, 2003) To achieve this, a supportive environment and positive attitudes are the crucial elements. Evidence shows that different ethnic groups are likely to have different supportive environments through their ongoing social interaction with their social networks, through which they are able to access different sources of capital, including finance, human and social capital. In addition, evidence shows that ethnic minorities tend to have different attitudes, motives and drive to start up their own business. Taking this forward, it can be inferred that different ethnic groups are embedded in different institutional contexts, with different cultural and societal environments which interact with their political and economic environment. As such the different ethnic groups are embedded in different enterprise cultures. It must be emphasised that enterprise culture is not a static phenomenon or sets of elements (Nicholson \& Anderson, 2005). On the contrary, it is embedded in the institutional context and is continuously reciprocally shaped, reshaped and reinforced by the institutional factors. The interplay between institutional context and enterprise culture suggests that a single, universal enterprise culture simply does not exist - instead different ethnic groups are embedded in different enterprise subcultures. As discussed earlier, enterprise subculture plays a key role in the entrepreneurial activities. To advance understanding of ethnic minority business, it is 
essential to understand the enterprise subcultures of the different ethnic groups. Only by understanding the different enterprise subcultures, can one then understand how and why there are different levels of entrepreneurial activity in different ethnic groups in a single country, under the same political and economic environments.

\section{Research Methods}

A questionnaire has been designed to cover the areas of individual profile and enterprise cultures. The intent of this paper is to present data related to the respondents' attitude towards entrepreneurship and to investigate their relationship with the respondents' enterprising experience and social context, using the respondents' ethnic origin as a differentiating factor. While quantitative research is preferred in this stage of the fieldwork, considering the major limitations of quantitative research, caution will be exercised in analysing and interpreting the data collected.

A major obstacle in researching ethnic minority business is gaining access to the informants from different ethnic groups (Monder Ram, 1996, 1999). To tackle this barrier, several means of overcoming the obstacles are utilised. These include using the business database, business support networks, yellow pages, researchers' personal contacts and 'snowballing'. To enhance the response rate of the survey, a mixed-mode survey is adopted in the first-stage fieldwork. A mixed-mode survey can offer the different response modes in either parallel or serial mode (Meckel et al., 2005). In this stage of fieldwork, a parallel mixed-mode is adopted which gives the respondents a choice of four different ways of responding: email, online, post or fax. As regarding gaining access to samples, a total of over 100 business networks and ethnic minority organisations in the UK were contacted in order to facilitate the participations of their members. Furthermore, 2,000 printed questionnaires were sent out by post to different regions in the UK. Postal codes and addresses were chosen from the Royal Mail database. Several cities were chosen because of their larger populations of ethnic minorities. In addition to this, the researchers have been actively engaged in networking events of different ethnic groups. On top of all these, the researchers' personal networks were utilised in order to widen the scope of participation.

A total of 213 questionnaires were received through webpage, post and emails. However, only 205 of these had sufficient data for our analysis, this including 96 female and 109 male respondents from seven different ethnic groups (Table 1). For the purpose of our analysis, all the non-White ethnic minorities are combined into one group: Ethnic Minorities. In what follows, the result on entrepreneurial attitude, experience and social activities of the two groups of respondents (White and Ethnic Minorities) will be presented.

Table 1. Sample size, gender and ethnicity

\begin{tabular}{|l|l|c|c|c|}
\hline \multicolumn{2}{|c|}{} & \multicolumn{2}{|c|}{ Gender } & Motal \\
\hline \multirow{3}{*}{ Ethnic Origin } & White & Female & 45 & 86 \\
\cline { 2 - 5 } & Indian & 41 & 21 & 45 \\
\cline { 2 - 5 } & Pakistani & 24 & 15 & 22 \\
\cline { 2 - 5 } & Chinese & 7 & 16 & 35 \\
\cline { 2 - 5 } & Black-African & 19 & 8 & 11 \\
\cline { 2 - 5 } & Black-Caribbean & 3 & 4 & 5 \\
\cline { 2 - 5 } & Others Total & 1 & 0 & 205 \\
\hline
\end{tabular}

\section{Data analysis and results}

\section{Personal characteristics}

The personal characteristics of the respondents were presented in Table 2, using ethnic origin as a differentiating factor. There is no significant difference in terms of the respondents' age or gender. However, significant difference was identified in the respondents' highest education level $\left(\chi^{2}=13.209, \mathrm{df}=3, \mathrm{p}<0.01\right), 21 \%$ of the Ethnic Minorities respondents, compared with 
$13 \%$ of the White respondents have postgraduate qualification; while $13 \%$ of the White respondents, compared with only $2 \%$ of the Ethnic Minorities respondents have professional qualifications.

Table 2. Respondents' Personal Characteristics

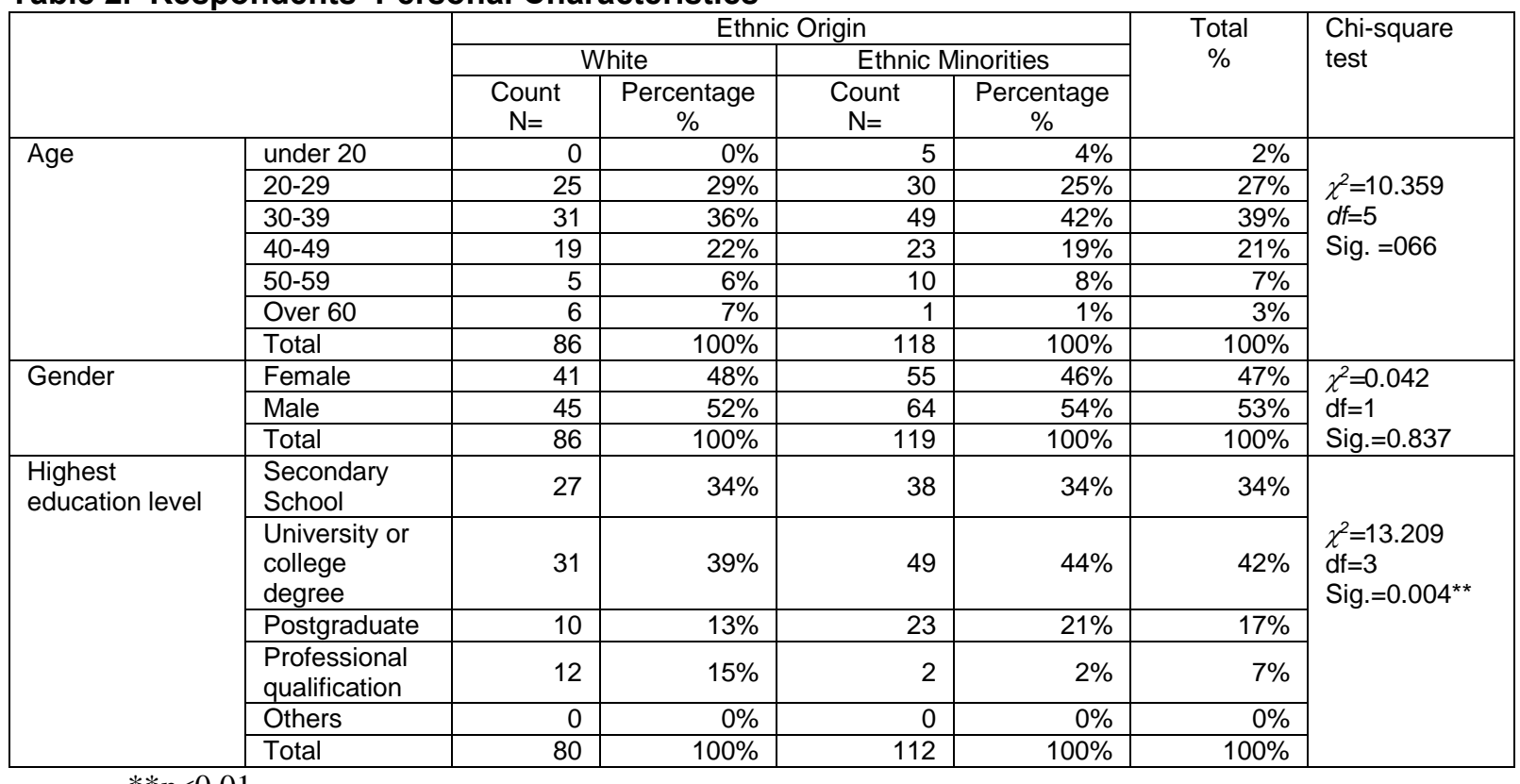

$* * p<0.01$

\section{Entrepreneurial Attitudes}

In this section, we are aiming at investigating the respondent's attitude towards entrepreneurship. Using a 5-point Likert-type scale, where 5 is strongly agree and 1 is strongly disagree, we asked the respondents to rate statements related to business ownership. Some of the statements were adopted from the Global Entrepreneurship Monitor (GEM) report. Considering the fact that respondents do not necessarily thought about entrepreneurship or business ownership in particular, we added 'Never thought about it' as one of choices in the question as it help to better capture the respondents' entrepreneurial thinking.

Our result show significant differences in all the seven statements. As shown in Table 3, the ethnic minority respondents are significantly more likely to have thought about the aspects that are related to business ownership, as compared to their White counterparts. This indicates that the ethnic minorities are more likely to have enterprise in mind, whether or not they have more positive attitude towards entrepreneurship. A t-test to compare means of the two groups of respondents about the above statements are then carried out, the analysis has excluded the respondents who has answered 'Never thought about it'.

As shown in Table 4, significant differences were identified in five out of the seven statements that related to aspects of business ownership. Though not statistical significant, our ethnic minority respondent score higher (mean=3.7) in the statement 'You like the idea of running your own business', as compared with their White counterparts (mean=3.36). Likewise, our White respondents score lower (mean=3.18) in the statement 'It is a desirable career to be $a$ business owner' than their ethnic minorities counterparts (mean=3.38). In other words, our ethnic minority respondents are more likely to agree to the positive aspect of business ownership and less likely to perceive running a business as risky $(\mathrm{t}=3.242, \mathrm{df}=170, p=0.001)$.

Table 3. Entrepreneurial Thinking of Respondents

\begin{tabular}{|c|c|c|c|c|c|}
\hline \multirow{2}{*}{$\begin{array}{l}\text { Ever thought about the following } \\
\text { statement: }\end{array}$} & & \multicolumn{2}{|c|}{ Ethnic Origin } & \multirow[b]{2}{*}{ Total } & \multirow[b]{2}{*}{ Chi-square test } \\
\hline & & White & $\begin{array}{c}\text { Ethnic } \\
\text { Minorities }\end{array}$ & & \\
\hline \multirow{2}{*}{$\begin{array}{l}\text { a) People you know respect those starting } \\
\text { a new business }\end{array}$} & Never & $21 \%$ & $39 \%$ & $28 \%$ & \multirow{2}{*}{$\begin{array}{c}\chi^{2}=7.636 \\
d f=1 \\
\text { Sig. }=.006^{* *}\end{array}$} \\
\hline & Yes & $79 \%$ & $61 \%$ & $72 \%$ & \\
\hline \multirow{2}{*}{$\begin{array}{l}\text { b) There are always opportunities for } \\
\text { starting a business }\end{array}$} & Never & $5 \%$ & $31 \%$ & $16 \%$ & \multirow{2}{*}{$\begin{array}{c}\chi^{2}=24.092 \\
\mathrm{df}=1\end{array}$} \\
\hline & Yes & $95 \%$ & $69 \%$ & $84 \%$ & \\
\hline
\end{tabular}




\begin{tabular}{|c|c|c|c|c|c|}
\hline & & & & & Sig. $=.000^{* * *}$ \\
\hline \multirow{2}{*}{$\begin{array}{l}\text { c) You like the idea of running your own } \\
\text { business }\end{array}$} & Never & $3 \%$ & $34 \%$ & $16 \%$ & \multirow{2}{*}{$\begin{array}{c}\begin{array}{c}\chi^{2}=32.887 \\
\mathrm{df}=1\end{array} \\
\text { Sig. }=.000^{\star * *}\end{array}$} \\
\hline & Yes & $97 \%$ & $66 \%$ & $84 \%$ & \\
\hline \multirow{2}{*}{$\begin{array}{l}\text { d) People you know envy those who make } \\
\text { a lot of money from starting a new } \\
\text { business }\end{array}$} & Never & $10 \%$ & $39 \%$ & $22 \%$ & \multirow{2}{*}{ 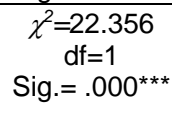 } \\
\hline & Yes & $90 \%$ & $61 \%$ & $78 \%$ & \\
\hline \multirow[t]{2}{*}{ e) It is risky to run a business } & Never & $3 \%$ & $29 \%$ & $14 \%$ & \multirow{2}{*}{ 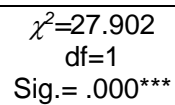 } \\
\hline & Yes & $97 \%$ & $71 \%$ & $86 \%$ & \\
\hline \multirow{2}{*}{$\begin{array}{l}\text { f) It is a desirable career to be a business } \\
\text { owner }\end{array}$} & Never & $6 \%$ & $30 \%$ & $16 \%$ & \multirow{2}{*}{$\begin{array}{c}\begin{array}{c}\chi^{2}=20.550 \\
d f=1\end{array} \\
\text { Sig. }=.000^{* * *}\end{array}$} \\
\hline & Yes & $94 \%$ & $70 \%$ & $84 \%$ & \\
\hline \multirow{2}{*}{$\begin{array}{l}\text { g) Business owners are more competent } \\
\text { and capable than employees }\end{array}$} & Never & $4 \%$ & $32 \%$ & $16 \%$ & \multirow{2}{*}{$\begin{array}{c}\chi^{2}=26.454 \\
d f=1 \\
\text { Sig. }=.000^{* \star *}\end{array}$} \\
\hline & Yes & $96 \%$ & $68 \%$ & $84 \%$ & \\
\hline
\end{tabular}

$$
* * p<0.01 \quad * * * p<0.001
$$

Table 4. T-Test of the statement related to entrepreneurship

\begin{tabular}{|c|c|c|c|c|c|c|}
\hline & & Count & Mean & $\mathrm{t}$ & $\mathrm{df}$ & $\begin{array}{c}\text { Sig. } \\
\text { (2-tailed) }\end{array}$ \\
\hline \multirow{2}{*}{$\begin{array}{l}\text { a) People you know respect those } \\
\text { starting a new business }\end{array}$} & White & 51 & 2.90 & \multirow{2}{*}{-3.954} & \multirow{2}{*}{141} & \multirow{2}{*}{$.000^{\star \star \star}$} \\
\hline & Ethnic Minorities & 92 & 3.59 & & & \\
\hline \multirow{2}{*}{$\begin{array}{l}\text { b) There are always opportunities for } \\
\text { starting a business }\end{array}$} & White & 58 & 2.98 & \multirow[b]{2}{*}{$-2.593^{\dagger}$} & \multirow[b]{2}{*}{141.441} & \multirow[b]{2}{*}{$.011^{\star *}$} \\
\hline & Ethnic Minorities & 110 & 3.45 & & & \\
\hline \multirow{2}{*}{$\begin{array}{l}\text { c) You like the idea of running your } \\
\text { own business }\end{array}$} & White & 55 & 3.36 & \multirow{2}{*}{-1.498} & \multirow{2}{*}{165} & \multirow{2}{*}{.136} \\
\hline & Ethnic Minorities & 112 & 3.70 & & & \\
\hline \multirow{2}{*}{$\begin{array}{l}\text { d) People you know envy those who } \\
\text { make a lot of money from starting a } \\
\text { new business }\end{array}$} & White & 51 & 3.00 & \multirow[b]{2}{*}{-2.462} & \multirow[b]{2}{*}{153} & \multirow[b]{2}{*}{$.015^{\star \star}$} \\
\hline & Ethnic Minorities & 104 & 3.59 & & & \\
\hline \multirow[t]{2}{*}{ e) It is risky to run a business } & White & 60 & 3.75 & \multirow[t]{2}{*}{3.242} & \multirow[t]{2}{*}{170} & \multirow[t]{2}{*}{$.001^{* *}$} \\
\hline & Ethnic Minorities & 112 & 3.14 & & & \\
\hline \multirow{2}{*}{$\begin{array}{l}\text { f) It is a desirable career to be a } \\
\text { business owner }\end{array}$} & White & 56 & 3.18 & \multirow{2}{*}{-1.068} & \multirow{2}{*}{162} & \multirow{2}{*}{.287} \\
\hline & Ethnic Minorities & 108 & 3.38 & & & \\
\hline \multirow{2}{*}{$\begin{array}{l}\text { g) Business owners are more } \\
\text { competent and capable than } \\
\text { employees }\end{array}$} & White & 58 & 2.07 & \multirow[b]{2}{*}{-4.656} & \multirow[b]{2}{*}{164} & \multirow[b]{2}{*}{$.000^{* * *}$} \\
\hline & Ethnic Minorities & 108 & 2.98 & & & \\
\hline
\end{tabular}

${ }^{\dagger}$ a t-test for unequal variances was used; $* * p<0.01 \quad * * * p<0.001$

\section{Entrepreneurial Social Context}

Networking activity, measured by frequency of interaction, has been explored in previous network studies of entrepreneurship with mix results ( $H$. Aldrich et al., 1989; Johannisson, 1988). In this section we aimed to investigate the respondents' social activities, in terms of frequency and content of their social interaction. First we asked the respondents how often they communicate with their social relations, this including their family members, kin, blood relatives and friends.

When asked how often they communicated with their family members who are living together, our analysis shows very similar results between our two groups respondent (85\%). However, there were significant differences between the two groups of respondents when we asked them how often they communicate with their family member not living together, relatives and friends. Ethnic minority respondents are more likely to communicate every week with their family member not living together $(58 \%)$ while our White respondents are more likely to communicate with their family members not living together on an irregular basis $(42 \%)$. The result also show that our ethnic minority respondents are more likely to communicate with their relatives more often, $13 \%$ of them communicate with their relative everyday, compared to only $6 \%$ of our White respondents; adding to a total of $48 \%$ communicate with their relatives at least once a week while only $36 \%$ communicate with their relatives at least once a week. There are also significant differences in terms of the respondents' communication frequency with their friends, although the figures look relatively close in aggregate level, with $73 \%$ of the White respondents and $66 \%$ of our ethnic minority respondents communicate with their friends at least once a week, there are significant differences in the two categories: $34 \%$ of our ethnic minority 
respondents communicate with their friends everyday, compared to only $10 \%$ of our White respondents. On the contrary, $63 \%$ of our White respondents communicate with their friends every week, compared to only $32 \%$ of our ethnic minority respondents.

Table 5. Networking activities - frequency

\begin{tabular}{|c|c|c|c|c|c|c|}
\hline \multirow{8}{*}{$\begin{array}{l}\text { How often do you } \\
\text { communicate with your: } \\
\text { Family members living } \\
\text { together }\end{array}$} & \multirow{3}{*}{$\begin{array}{l}\text { Frequency } \\
\text { Everyday }\end{array}$} & \multicolumn{2}{|c|}{ Ethnic Origin } & \multirow[b]{2}{*}{ Total } & \multirow{2}{*}{\multicolumn{2}{|c|}{ Chi-Square Analysis }} \\
\hline & & \multirow{2}{*}{$\begin{array}{c}\text { White } \\
85 \%\end{array}$} & \multirow{2}{*}{$\begin{array}{c}\begin{array}{c}\text { Ethnic } \\
\text { Minorities }\end{array} \\
85 \%\end{array}$} & & & \\
\hline & & & & $85 \%$ & $x^{2}$ & 6.496 \\
\hline & Every week & $9 \%$ & $6 \%$ & $7 \%$ & $d f$ & 4 \\
\hline & Every month & $1 \%$ & $3 \%$ & $2 \%$ & Sig. & .165 \\
\hline & $\begin{array}{l}\text { Irregular basis, only } \\
\text { occasionally }\end{array}$ & $0 \%$ & $4 \%$ & $2 \%$ & & \\
\hline & Very rarely, almost never & $5 \%$ & $2 \%$ & $3 \%$ & & \\
\hline & Total & $100 \%$ & $100 \%$ & $100 \%$ & & \\
\hline \multirow{6}{*}{$\begin{array}{l}\text { Family members not living } \\
\text { together }\end{array}$} & Everyday & $8 \%$ & $15 \%$ & $12 \%$ & $\chi^{2}$ & 28.652 \\
\hline & Every week & $40 \%$ & $58 \%$ & $51 \%$ & $d f$ & 4 \\
\hline & Every month & $10 \%$ & $15 \%$ & $13 \%$ & Sig. & $.000^{\star * \star}$ \\
\hline & $\begin{array}{l}\text { Irregular basis, only } \\
\text { occasionally }\end{array}$ & $42 \%$ & $10 \%$ & $23 \%$ & & \\
\hline & Very rarely, almost never & $0 \%$ & $2 \%$ & $1 \%$ & & \\
\hline & Total & $100 \%$ & $100 \%$ & $100 \%$ & & \\
\hline \multirow{6}{*}{$\begin{array}{l}\text { Relative (kin, blood } \\
\text { relatives) }\end{array}$} & Everyday & $6 \%$ & $13 \%$ & $10 \%$ & $\chi^{2}$ & 40.198 \\
\hline & Every week & $21 \%$ & $35 \%$ & $30 \%$ & $d f$ & 4 \\
\hline & Every month & $10 \%$ & $31 \%$ & $22 \%$ & Sig. & $.000^{\star * \star}$ \\
\hline & $\begin{array}{l}\text { Irregular basis, only } \\
\text { occasionally }\end{array}$ & $60 \%$ & $19 \%$ & $36 \%$ & & \\
\hline & Very rarely, almost never & $4 \%$ & $1 \%$ & $2 \%$ & & \\
\hline & Total & $100 \%$ & $100 \%$ & $100 \%$ & & \\
\hline \multirow[t]{6}{*}{ Friends } & Everyday & $10 \%$ & $34 \%$ & $24 \%$ & $x^{2}$ & 24.154 \\
\hline & Every week & $63 \%$ & $32 \%$ & $45 \%$ & $d f$ & 4 \\
\hline & Every month & $11 \%$ & $14 \%$ & $13 \%$ & Sig. & $.000^{\star * *}$ \\
\hline & $\begin{array}{l}\text { Irregular basis, only } \\
\text { occasionally }\end{array}$ & $15 \%$ & $16 \%$ & $16 \%$ & & \\
\hline & Very rarely, almost never & $1 \%$ & $3 \%$ & $2 \%$ & & \\
\hline & Total & $100 \%$ & $100 \%$ & $100 \%$ & & \\
\hline
\end{tabular}

The results of our analysis show very different patterns of social interaction among our respondents from different ethnic origins; this may have implications in the content of their social interaction. The second part of this section we look at the content of the social interaction. It is argued that the content of social interaction play a key role in shaping the shared value among the social groups and their attitude towards entrepreneurship (Lam, 2004, 2007). Having identified a few key aspects that are believed to have related to positive meanings of entrepreneurship, we asked the respondent how likely they have talked about these aspects in their social gatherings.

Table 6. Content of social interaction

\begin{tabular}{|c|c|c|c|c|c|c|}
\hline & & $\mathrm{N}$ & Mean & $t$ & df & Sig (2-tailed) \\
\hline \multirow{2}{*}{$\begin{array}{l}\text { Wealth of certain people/family that } \\
\text { is known in the social network }\end{array}$} & White & 82 & 1.62 & $-13.212^{\dagger}$ & 197.719 & $.000^{\star \star \star}$ \\
\hline & Ethnic Minorities & 118 & 3.65 & & & \\
\hline \multirow{2}{*}{$\begin{array}{l}\text { Achievement or occupation of } \\
\text { certain people in the network }\end{array}$} & White & 82 & 2.56 & $-8.917^{\dagger}$ & 156.032 & $.000^{\star \star \star}$ \\
\hline & Ethnic Minorities & 118 & 3.98 & & & \\
\hline \multirow{2}{*}{$\begin{array}{l}\text { Achievement of the relatives' } \\
\text { children in school }\end{array}$} & White & 82 & 2.77 & $-5.691^{\dagger}$ & 148.476 & $.000^{* * *}$ \\
\hline & Ethnic Minorities & 117 & 3.67 & & & \\
\hline \multirow{2}{*}{$\begin{array}{l}\text { Business related topics (eg. } \\
\text { finance, people, business idea) }\end{array}$} & White & 83 & 1.84 & $-11.207^{\dagger}$ & 198.791 & $.000^{\star \star \star}$ \\
\hline & Ethnic Minorities & 118 & 3.57 & & & \\
\hline
\end{tabular}

ta t-test for unequal variances was used; $* * * p<0.001$

As shown in Table 6, significant differences were found in all the four aspects. Our ethnic minority respondents are significantly more likely to talk about wealth $(p<0.001)$ and achievement/occupation $(p<0.001)$ of their social network; they are more likely to talk about the achievement of the relatives' children in school $(p<0.001)$ and most importantly, they are more likely to talk about business related topics in their social gatherings $(p<0.001)$. This helps to reveal a different picture of social gatherings between different ethnic origins, with the content of the ethnic minorities' social gatherings appears to be more entrepreneurship related. 


\section{Discussion \& Conclusion}

The results of our analysis have suggested a number of interesting observations. Firstly our analysis shows that our ethnic minority respondents have significantly more positive attitude towards entrepreneurship. This has supported findings of previous studies in this aspect (GEM, 2018; Linehan \& Sosna, 2004; Waistad \& Kourilsky, 1998; Wilson et al., 2004). Our results also show that the ethnic minority respondents have different patterns of social interaction: they are more likely to communicate with their family members not living together, relatives, kin and blood relatives more often than their White counterparts. Furthermore, the results show that our ethnic minority respondents tend to communicate with their friends more often, a significant number of them communicate with their friends everyday, while majority of our White respondents communicate with their friends on a weekly basis.

The difference may be due to the different forms of social activities that are institutionalised in different ethnic group. In her studies, Lam (2004) argued that in certain ethnic groups, social activities such as wedding, birthday parties, new year parties or regular meals with social relations are institutionalised in the social groups, fail to attend them will be considered as offending the host or other members in the social network. As a consequence of the institutionalised form and frequency of social activities, members of the social groups meet up regularly, which then form the key platform of their ongoing social interaction. To further understanding of the ongoing social interaction, we then analyse the content of the social interaction. The result show significant differences in the content of their social activities between our White and non-White ethnic minority respondents. During their social gatherings, our ethnic minority respondents are more likely to talk about topics such as wealth and achievement of their social network, which is believed to be associated with the positive meanings of entrepreneurship in the social group (Lam, 2004). Furthermore, ethnic minority respondents are more likely to talk about business related topics in social activities. As a consequence, the institutionalised social gatherings may act like ongoing, informal business seminars that help to enhance the individuals' entrepreneurship knowledge (Redding, 1990). In other words, while social gathering may be considered as leisure time for our White respondents, they may be part of the entrepreneurial learning process for our ethnic minority respondents.

From an enterprise culture perspective, our findings suggest that White and Non-White ethnic minority respondents are embedded in significantly different enterprise culture. They hold different value and attitude towards entrepreneurship; they have different level of knowledge and experience about entrepreneurship; most importantly, they learn about entrepreneurship differently. Our ethnic minority respondents see, hear and learn about entrepreneurship throughout their upbringing: through their ongoing social interaction and different forms of institutionalised social activities. On the other hand, our White respondents probably learnt about entrepreneurship through more 'remote' way such as formal education or media. The social context, reciprocally, helps the ethnic minority respondents to enhance their entrepreneurial experience and attitude towards entrepreneurship.

Our study has important implications for policy makers and business support agencies. For example, the importance of social networks in entrepreneurship is repeatedly supported by previous studies (Howard Aldrich et al., 1987; Howard Aldrich \& Zimmer, 1986; Karra et al., 2006; Rouse \& Boles, 2005; Standifird, 2006; Witt, 2004). This has been responded by public policy which focuses on networks and networking linking to business support provision in areas including finance, advice, training and/or mentoring programmes. Key activities involve creating networks of local and regional business groups, partnerships with existing networks and establishing new industry networks where needed. This is then followed by measurement criteria which mainly focus on the quantity of networks created, the number of members joining the networks and the usages of business support services etc. Apart from the self-reported 'success' of these policies, there is no convincing evidence that these policies has effectively enhance the role entrepreneurship play in the economies. One key drawback is these policies has taken the notion of 'network' and 'networking' out of context, as such what give rise to the networks and networking activities in certain ethnic groups are largely ignored. Furthermore, how and why these networking events maintain on an ongoing basis in certain ethnic groups, 
across national boundaries are questions left unanswered. From an enterprise culture perspective, the forms, frequency and content of social activities are part of a complex, reciprocal ongoing process. In our studies, we found that the individuals' attitudes towards entrepreneurship are associated with their social networks, entrepreneurial experience and shared value among the social group; furthermore, it is associated with how and what they communicate with their social relations. None of the above factors can be singled out as the most important, yet each of them has a role to play shaping their entrepreneurial attitude. It is therefore important for policy makers to appreciate the complexity of social embeddedness and its association with entrepreneurship within different social context, without adequate understanding of the complex social interaction process, it is unlikely that any policy can be effective and efficiency in fostering entrepreneurship.

\section{Contribution to Knowledge, Limitation and Future Research}

A major contribution of this study is the theoretical development in advancing understanding of ethnic minority entrepreneurship. An enterprise culture perspective is presented which helps depict the social context of ethnic minorities in the process of entrepreneurship. The discussion presented helps advance understanding of the complex issues related to ethnic minority entrepreneurship; issues such as attitude, entrepreneurial thinking, experience and social activities. For policy makers, this study provides insight into the interrelationship and implications between social context and ethnic minority entrepreneurship which are crucial in enhancing the effectiveness and efficiency of public policy. Furthermore, the theoretical and methodological framework developed for this study helps lay a foundation for further research in understanding ethnic minority entrepreneurship from an alternative view.

As mentioned, the data presented only cover the comparison between White and Non-White respondents. The heterogeneity between different ethnic groups is well supported in the extant literature (Monder Ram, 1997; Moder Ram et al., 2000). Our future research agenda include data analysis of different ethnic groups (Indian, Pakistani, Chinese and Black etc.). A limitation of this study is that it has employed a relatively small sample size and is focused mainly on quantitative research. It is expected that this studies can be enriched by our subsequent fieldwork, which involves in-depth qualitative research such as face-to-face interviews, focus groups, ethnographic research and longitudinal studies.

\section{References}

Aldrich, H., Cater, J., Jones, T., McEvoy, D., \& Velleman, P. (1985). Ethnic Residential Concentration and the Protected Market Hypothesis. Social Forces, 63(4), 996-1009.

Aldrich, H., Reese, P. R., \& Dubini, P. (1989). Women on verge of a breakthrough: networking among entreprenurs in the United States and Italy. Entrepreneurship and Regional Development, 1(4), 339-356.

Aldrich, H., Rosen, B., \& Woodward, W. (1987). The impact of social networks on business founding and profit: a longitudinal study. In N. C. Churchill, J. A. Hornaday, B. A. Kirchhoff, O. J. Krasner \& K. H. Vesper (Eds.), Frontiers of Entrepreneurship Research (pp. 154-168). Wellesley, MA: Babson College.

Aldrich, H., \& Waldinger, R. (1990). Ethnicity and entrepreneurship. Annual Review of Sociology, 16, 111-135.

Aldrich, H., \& Zimmer, C. (1986). Entrepreneurship through social networks. In D. L. Sexton \& R. W. Smilor (Eds.), The Art and Science of Entrepreneurship (pp. 3-23). Cambridge: Ballinger.

Ang, S. H., \& Hong, D. G. P. (2000). Entrepreneurial spirit among East Asian Chinese. Thunderbird International Business Review, 42(3), 285-310.

Bagwell, S. (2015). Transnational Entrepreneurship amongst Vietnamese Businesses in London. Journal of Ethnic and Migration Studies, 41(2), 329-349. doi: 10.1080/1369183X.2014.907739

Bates, T. (1997). Financing small business creation: the case of Chinese and Korean immigrant entrepreneurs. Journal of Business Venturing, 12(2), 109-124.

Braadbaart, O. (1995). Source of ethnic advantage - A comparison of Chinese and pribumimanaged engineering firms in Indonesia. In R. A. Brown (Ed.), Chinese Business Enterprise in Asia (pp. 177-196). London: Routledge. 
Burrows, R., \& Curran, J. (1991). Not such a small business: reflections on the rhetoric, the reality and the future of the enterprise culture. In M. Cross \& G. Payne (Eds.), Work and the Enterprise Culture (pp. 9-29). London: The Flamer Press.

Carino, T. C. (1995). The ethnic Chinese, the Philippines economy and China. In L. Suryadinata (Ed.), Southeast Asian Chinese and China - the Politico-Economic Dimension (pp. 216229). Singapore: Times Academic Press.

Chan, K.-B., \& Chiang, C. S.-N. (1994). Stepping Out - The Making of Chinese Entrepreneurs. Singapore: Simon \& Schuster (Asia).

Chapman, D. (2003). Enterprise Culture. New Zealand Management, 50(10), 20-21.

Clark, K., \& Drinkwater, S. (2000). Pushed out or pulled in? Self-employment among ethnic minorities in England and Wales. Labour Economics, 7, 603-628.

Cohen, L., \& Musson, G. (2000). Entrepreneurial identities: reflections from two case studies. Organization.

Collins, L. A., \& Fakoussa, R. (2015). Ethnic minority entrepreneurship: an examination of Pakistani entrepreneurs in the UK. Journal of Innovation and Entrepreneurship, 4(1), 121. doi: $10.1186 / \mathrm{s} 13731-014-0013-1$

Fairlie, R. W., \& Meyer, B. (1996). Ethnic and racial self-employment differences and possible explanations. Journal of Human Resources, 31, 757-793.

GEM. (2017). Global Entrepreneurship Monitor: United Kingdom 2017 Monitoring Report: University of Strathclyde, Queen's University Belfast, Aston Business School.

GEM. (2018). Global Entrepreneurship Monitor 2018/19 Global Report: Babson College, USA.

Gibb, A. A. (1987). Enterprise Culture - Its Meaning and Implications for Education and Training. Journal of European Industrial Training, 11(2), 1-38.

Godley, A. (1996). Jewish soft loan societies in New York and London and immigrant entrepreneurship. Business History, 38(3), 101-116.

Granovetter, M. (1985). Economic action and social structure: the problem of embeddedness. American Journal of Sociology, 91(3), 481-510.

Green, S. D., \& May, S. C. (2003). Re-engineering construction: going against the grain. Building Research \& Information, 31(2), 97-106.

Haley, G. T., Tan, C. T., \& Haley, U. C. V. (1998). New Asian Emperors - The Overseas Chinese, their Strategies and Competitive Advantages. Oxford: Butterworth Heinemann.

Haugen, H. O., \& Carling, J. (2005). On the edge of the Chinese diaspora: the surge of baihuo business in an African city. Ethnic and Racial Studies, 28(4), 639-662.

Hirschman, C. (1982). Immigrants and minorities: old questions for new directions in research. Interantional Migration Review, 16, 474-490.

Hodder, R. (1994). Merchant Princes of the East. Singapore: John Wiley \& Sons.

Johannisson, B. (1988). Business formation: a network approach. Scandinavian Journal of Management, 4(3/4), 83-99.

Jones, T., Mascarenhas-Keyes, S., \& Ram, M. (2012). The Ethnic Entrepreneurial Transition: Recent Trends in British Indian Self-Employment. Journal of Ethnic and Migration Studies, 38(1), 93-109. doi: 10.1080/1369183X.2012.640020

Jones, T., \& Ram, M. (2003). South Asian business in retreat? The case of the UK. Journal of Ethnic \& Migration Studies, 29(3), 485-500.

Jones, T., Theodorakopoulos, N., \& Ram, M. (2010). Transnationalism as a Force for Ethnic Minority Enterprise? The Case of Somalis in Leicester. International Journal of Urban and Regional Research, 34(3), 565-585. doi: 10.1111/j.1468-2427.2010.00913.x

Karra, N., Tracey, P., \& Phillips, N. (2006). Altruism and agency in the family firm: exploring the role of family, kinship, and ethnicity. Entrepreneurship: Theory \& Practice, 30(6), 861877.

Khosravi, S. (1999). Displacement and entrepreneurship: Iranian small business in Stockholm. Journal of Ethnic \& Migration Studies, 25(3), 493-508.

Lam, W. (2004). New Venture Creation in two Chinese Subcultures: Hong Kong and Shanghai. (Ph.D thesis Ph.D thesis), Nottingham Trent University, UK, Nottingham.

Lam, W. (2007). Understanding the process of creating, maintaining and 'reproducing' family business. Paper presented at the Babson College Entrepreneurship Research Conference 7-9 June, Madrid, Spain.

Legge, K. (1995). Human Resource Management: Rehetorics and Realities. London: Macmillan.

Leung, M. W. H. (2001). Get IT going: new ethnic Chinese business. The case of Taiwaneseowned computer firms in Hamburg. Journal of Ethnic and Migration Studies, 27(2), 277294. 
Light, L. (1972). Ethnic Enterprise in America. Berkeley: University of California Press.

Linehan, L., \& Sosna, E. (2004). Engaging Black and Minority Ethnic Entrepreneurs in Business Support: Small Business Service.

Marger, M. N. (2001). The use of social and human capital among Canadian business immigrants. Journal of Ethnic \& Migration Studies, 27(3), 439-453.

Meckel, M., Walters, D., \& Baugh, P. (2005). Mixed-mode surveys using mail and web questionnaires. Electronic Journal of Business Research Methodology, 3(1), 69-80.

Min, P. G. (1988). Ethnic Business Enterprises: Korean Small Business in Atlanta. New York: CMS.

Nicholson, L., \& Anderson, A. R. (2005). News and nuances of the entrepreneurial myth and metaphor: linguistic games in entrepreneurial sense-making and sense-giving. Entrepreneurship Theory and Practice, 29(2), 153-172.

Orru, M. (1997). The institutional logic of small firm economies in Italy and Taiwan. In M. Orru, N. W. Biggart \& G. G. Hamilton (Eds.), The Economic Organization of East Asian Capitalism (pp. 340-367). London: SAGE.

Ram, M. (1994). Unravelling social networks in ethnic minority firms. International Small Business Journal, 12(3), 42.

Ram, M. (1996). Uncovering the Management Process: An Ethnographic Approach. British Journal of Management, 7(1), 35-44.

Ram, M. (1997). Ethnic minority enterprise: an overview and research agenda. International Journal of Entrepreneurial Behaviour \& Research, 3(4), 149-156.

Ram, M. (1999). Trading places: the ethnographic process in small firms' research. Entrepreneurship \& Regional Development, 11, 95-108.

Ram, M., Sanghera, B., Abbas, T., Barlow, G., \& Trevor, J. (2000). Ethnic minority business in comparative perspective: the case of the independent restaurant sector. Journal of Ethnic \& Migration Studies, 26(3), 495-510.

Ram, M., \& Smallbone, D. (2003). Policies to support ethnic minority enterprise: the English experience. Entrepreneurship \& Regional Development, 15(2), 151-166.

Redding, S. G. (1990). The Spirit of Chinese Capitalism. New York: Walter de Gruyter.

Redding, S. G., \& Whitley, R. D. (1990). Beyond Bureaucracy: towards a comparative analysis of forms of economic resource co-ordination and control. In S. R. Clegg \& S. G. Redding (Eds.), Capitalism in Contrasting Cultures (pp. 79-104). Berlin: Walter de Gruyter.

Ritchie, J. (1991). Enterprise cultures: a frame analysis. In R. Burrows (Ed.), Deciphering the Enterprise Culture (pp. 17-34). London: Routledge.

Rouse, J., \& Boles, K. (2005). The Big NES Survey 2004: An Evaluation of the Experience of New Entrepreneurs Scholars (pp. 1-126). Manchester: Centre for Enterprise.

SBS. (2003). Building an Enterprise Culture: Small Business Service, Department of Trade and Industry, UK.

Silverman, R. M. (1999). Ethnic solidairty and Black business: the case of ethnic beauty aids distributors in Chicago. American Journal of Economics and Sociology.

Smallbone, D., Ram, M., Deakins, D., \& Baldock, R. (2003). Access to finance by ethnic minority businesses in the UK. International Small Business Journal, 21(3), 291-314.

Standifird, S. S. (2006). Using Guanxi to Establish Corporate Reputation in China. Corporate Reputation Review, 9(3), 171-178.

Suryadinata, L. (1995). China's economic modernization and the ethnic Chinese in ASEAN: a preliminary study. In L. Suryadinata (Ed.), Southeast Asian Chinese and China - the Politico-Economic Dimension (pp. 193-215). Singapore: Times Academic Press.

Teixeira, C. (2001). Community resources and opportunities in ethnic economies: a case study of Portuguese and Black entrepreneurs in Toronto. Urban Studies, 11, 2055-2078.

Thornton, P. H. (1999). The Sociology of Entrepreneurship. Annual Review of Sociology, 25, 1946.

Waistad, W. B., \& Kourilsky, M. L. (1998). Entrepreneurial Attitudes and Knowledge of Black Youth. Entrepreneurship: Theory \& Practice, 23(2), 5-18.

Waldinger, R., Aldrich, H. E., \& Ward, R. (1990). Immigrant Entrepreneurs: Immigrant and Ethnic Business in Western Industrial Societies. Beverly Hills, CA: SAGE.

Weidenbaum, M., \& Hughes, S. (1996). The Bamboo Network - How Expatriate Chinese Entrepreneurs are Creating a New Economic Superpower in Asia. New York: Martin Kessler Books. 
Wilson, F., Marlino, D., \& Kickul, J. (2004). Our entrepreneurial future: examining the diverse attitudes and motivations of teens across gender and ethnic identity. Journal of Developmental Entrepreneurship, 9(3), 177-197.

Witt, P. (2004). Entrepreneurs' networks and the success of start-ups. Entrepreneurship \& Regional Development, 16(5), 391-412.

Wong, K. S. (1995). The ethnic Chinese in Southeast Asia and China. In L. Suryadinata (Ed.), Southeast Asian Chinese and China - the Politico-Economic Dimension (pp. 9-11). Singapore: Times Academic Press.

Wright, L. T., Martin, L. M., \& Stone, M. (2003). Exploring the characteristics, attitudes to targeting and relationship marketing of small ethnic minority businesses. Journal of Targeting, Measurement and Analysis for Marketing, 12(2), 173-184. 